\title{
Behind the Volatility of Beef Price in Indonesia
}

\author{
Made Antara ${ }^{\rtimes}$ \\ Made Sri Sumarniash ${ }^{2}$
}

'Agribusiness Study Program, Faculty of Agriculture, Udayana University, Bali, Indonesia

Email:_antara_unud@yahoo.com

'Agroecotechnology Study Program, Faculty of Agriculture, Udayana University, Bali, Indonesia

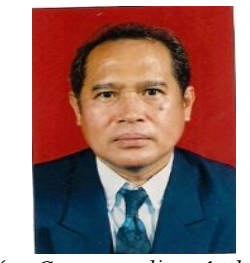

( Corresponding Author)

\section{Abstract}

The majority of Indonesian people fond of beef, so beef into meat favourit among other meats. Local beef cattle population which became a source of national beef production is likely to increase average $2.72 \%$ per year over a period of 16 years (2000 to 2016). The volatility of beef in Indonesia who had reached $\mathrm{Rp}$ 150,000 per $\mathrm{kg}$ before near the Eid al-Fitr 2015 has been troubling and troubling consumer society beef. This turbulence leads to an imbalance between consumption and production of local beef, where comsuption exceeds production, resulting in a deficit of beef. Based on projected production and consumption of beef, until 2019 Indonesia still deficit of beef. However behind the price volatility of beef in Indonesia, not only because of deficit of meat, but also the existence of a cartel of beef trade. Cartels are agreements some traders in setting the price of meat high in order to reach the high profit. The government, through the Business Competition Supervisory Commission (Komisi Pengawas Persaingan Usaha, KPPU) has fined 32 feedloter accused cartel of beef trade.

Keywords: Beef, Meat deficit, Volatility of prices, Cartel.

JEL Classification: D43.

Citation | Made Antara; Made Sri Sumarniash (2019). Behind the Volatility of Beef Price in Indonesia. Economy, 6(1): 1-6. History:

Received: 8 October 2018

Revised: 13 November 2018

Accepted: 19 December 2018

Published: 28 January 2019

Licensed: This work is licensed under a Creative Commons Attribution 3.0 License (cc) $\mathbf{E}$

Publisher: Asian Online Journal Publishing Group
Contribution/Acknowledgement: Both authors contributed to the conception and design of the study.

Funding: This study received no specific financial support

Competing Interests: The authors declare that they have no conflict of interests.

Transparency: The authors confirm that the manuscript is an honest, Transparency: The authors confirm that the manuscript is an honest,
accurate, and transparent account of the study was reported; that no vital accurate, and transparent account of the study was reported; that no vital
features of the study have been omitted; and that any discrepancies from the study as planned have been explained.

Ethical: This study follows all ethical practices during writing.

\section{Contents}

1. Introduction.

2. Population Development of Beef Cattle.

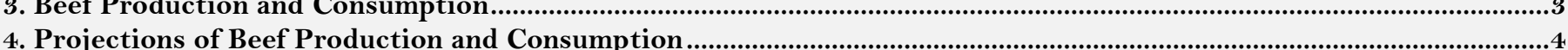

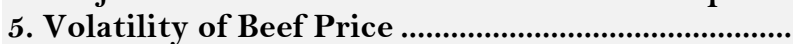

6. Conclusions and Recommendations..

References. 


\section{Introduction}

Along with the increase in population and improvement in the standard of living of the population in Indonesia, the demand for food for the fulfillment of nutrition is increasing. Beef is one of the food sources of animal protein that has a major contribution to the fulfillment of community nutrition in supporting the development of Indonesia's human resources. Unfortunately (Supardi, 2009) states that beef is a source of animal protein fulfilling a very good nutritional standard for consumption in order to live a healthy and intelligent life.

Indonesian people who like meat (except vegetarian groups), beef is halal meat, tasty, tender, and high in protein, so it cannot be separated from the daily menu. Eating on Eid al-Fitr feels incomplete if there are no beef dishes. This makes beef the most excellent meat from several other types of meat. When beef had penetrated the price of IDR 120,000 per $\mathrm{kg}$, people were restless and anxious, but this was not the case when other types of meat increased in price. Dwiyanto and Mahendri (2013) stated that beef is a "desire" for urban communities that are economically strong and have high purchasing power. Whereas for some residents who live in rural areas or those with limited economic levels, beef "is not a basic necessity" because they are not culturally "meat eaters".

Demand for beef tends to increase every year, both due to an increase in population, as well as an increase in meat consumption per capita per year due to increased income. Increased awareness of the population is important to consume enough protein sources also encourage increased demand for protein-based food ingredients such as meat, so that the pattern of consumption of society also changes. Initially more Indonesian people consume carbohydrates, but now they consume a lot of meat, eggs and milk. To meet protein requirements from chickens and eggs can be fulfilled from within the country, but milk and beef still need to be imported.

Beef trade in Indonesia, not only trades local beef and imported beef, but also involves many business people ranging from importers, feedloters, abattoirs, wholesalers and retailers. These traffickers are numerous, so that competition arises between them, even an evil agreement arises between them.

Business competition is increasing as the world economy increases. The desire to use all means to win the competition (Machiavellian), strategy, tactics, techniques are sought to lead consumers \& prospective consumers to use certain products. Organizations/companies collaborate, cooperate and coordinate to capture opportunities to dominate the market. Cartel, monopoly, monopsony, etc. emerged. The emergence of the cartel is basically based on the increasingly competitive conditions in the era of globalization. Although it is more likely to be negative because it harms the public, the cartel will still emerge because of the demands of business people and consumers. In the beef trade in Indonesia, indications of a cartel were detected, so the government took action to prevent it from suffering from their conspiracy.

The purpose of this paper is to explore and then describe why the price of beef in Indonesia often fluctuates on the one hand, while on the other hand the population of local beef cattle tends to increase from year to year thanks to various government programs. What's behind the turmoil of beef prices. This paper tries to reveal it.

\section{Population Development of Beef Cattle}

Looking at beef cattle population data by Province in Indonesia published by CBS (2017) it appears that in the last 16 years (2000-2016) beef cattle populations in Indonesia tended to increase (Figure 1). The population of beef cattle in 2000 was 11,008,017, ten years later in 2010 the population increased to $13,581,570$ or increased by $2.34 \%$ per year. Six years later in 2016 the population of beef cattle increased to 16,092,561 tails or increased by $3.08 \%$ per year. If observed per province, East Java is the province with the largest beef cattle population, namely in 2000 as many as 3,312,015 birds, in 2010 it increased to 3,745,453 birds and in 2016 it increased to 4,534,460 tails. While the beef cattle population in Bali in 2000 was 529,074 , ten years later in 2010 the population increased to 683,800 and six years later in 2016 the cattle population declined to 559,517. Anonymous (2012) informed that Bali is one of the suppliers of live cattle for the DKI Jakarta beef market.

Based on the last year cattle population (2016), the 10 largest provinces were beef cattle population centers, namely (1) East Java (28.18\%), (2) Central Java (10.45\%), (3) South Sulawesi (8, 41\%), (4) West Nusa Tenggara (6.84\%), (5) East Nusa Tenggara (5.79\%), (6) North Sumatra (4.25\%), (7) Lampung (4.11\%), (8) Aceh (3.73\%), (9) Bali $(3.48 \%)$, and (10) West Sumatra (2.51\%). Interestingly, the cattle population in East Nusa Tenggara (NTT) Province in 2000 was higher than the cattle population in the West Nusa Tenggara Province (NTB). But 16 years later in 2016 the cattle population in NTT was lower than the cattle population in NTB.

The cattle population in Indonesia must be increased to increase meat supply to the market in balance with increasing demand for beef. Breakthrough programs must be rolled out to stimulate cattle farmers and prospective breeders to raise beef cattle. In an effort to improve the quality and quantity of cattle owned by farmers, Muladno (2012) suggests the implementation of breeding programs through a business institutional approach so that the implementation of feed, genetic and reproductive technology can be carried out maximally, thereby increasing fire productivity and ensuring quality sustainability. But Kompas (2017) through the advertorial column page 12, entitled "Beating Self-Sufficiency of Beef with Insurance", informs how the relation between cattle insurance and beef self-sufficiency? First, increased motivation to raise cattle, so that the addition of cattle population is more guaranteed. Second, reducing the risk of loss in raising cattle, so that farmers are more willing to expand their business and more likely to increase the cattle population. Third, with insurance coverage, bank loans and microfinance institutions for cattle will increase. 


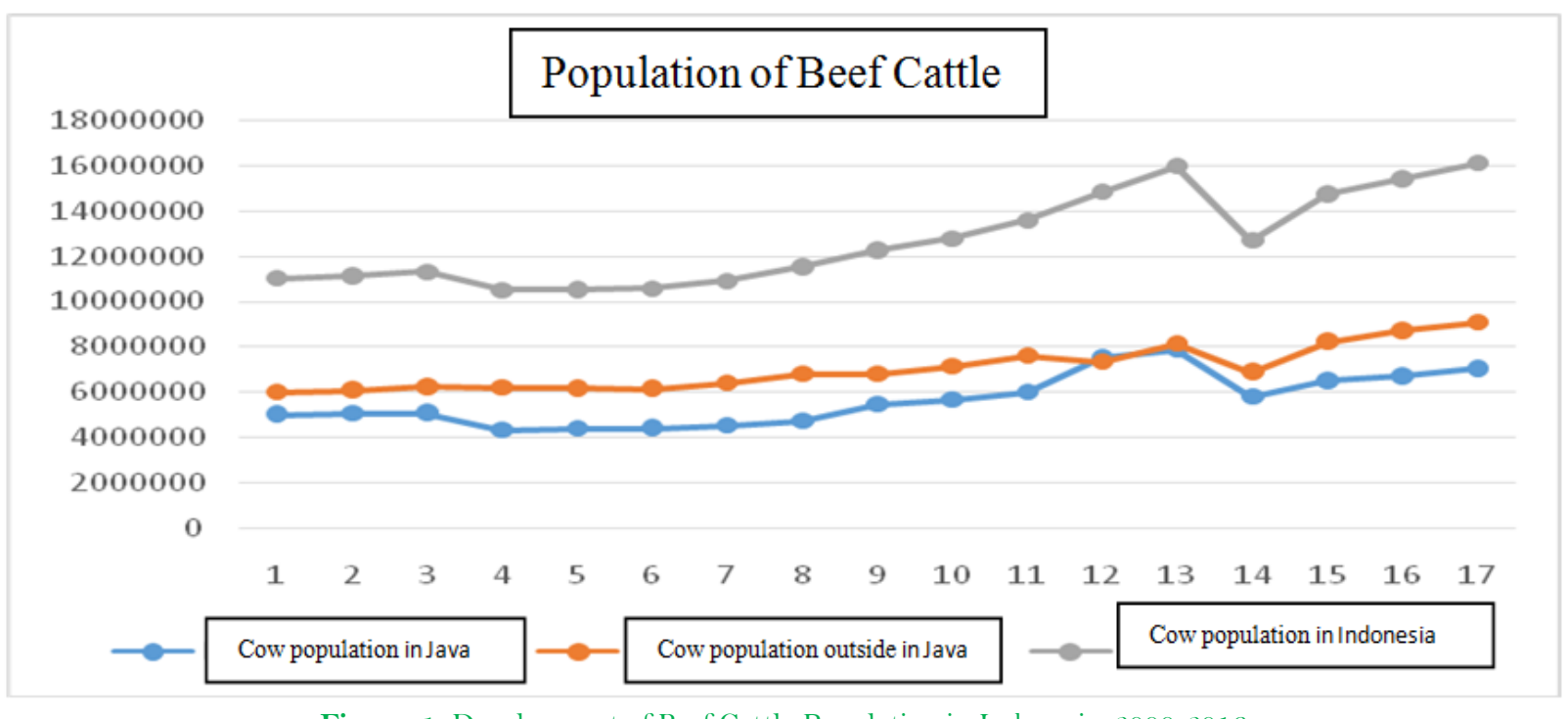

(Note: $1=$ Year 2000; $17=$ Year 2016)

\section{Beef Production and Consumption}

\subsection{Beef Production}

According toNuryati et al. (2015) the development of beef production in Indonesia in the period 1984-2015 generally had a similar pattern in Java and outside Java, which tended to increase (Figure 2). During this period, beef production in Indonesia increased by an average of $2.68 \%$ per year. The development of production in Java is $2.41 \%$ and outside Java is $4.44 \%$ per year. The production of beef in Indonesia in 1984 amounted to 248.48 thousand tons and in 2015 it increased to 523.93 thousand tons. The development of beef production in the last five years has tended to decline, this has something to do with the increasing increase in beef prices. Even though the price of beef is still high, the prediction of beef production per year will increase by $5.28 \%$.

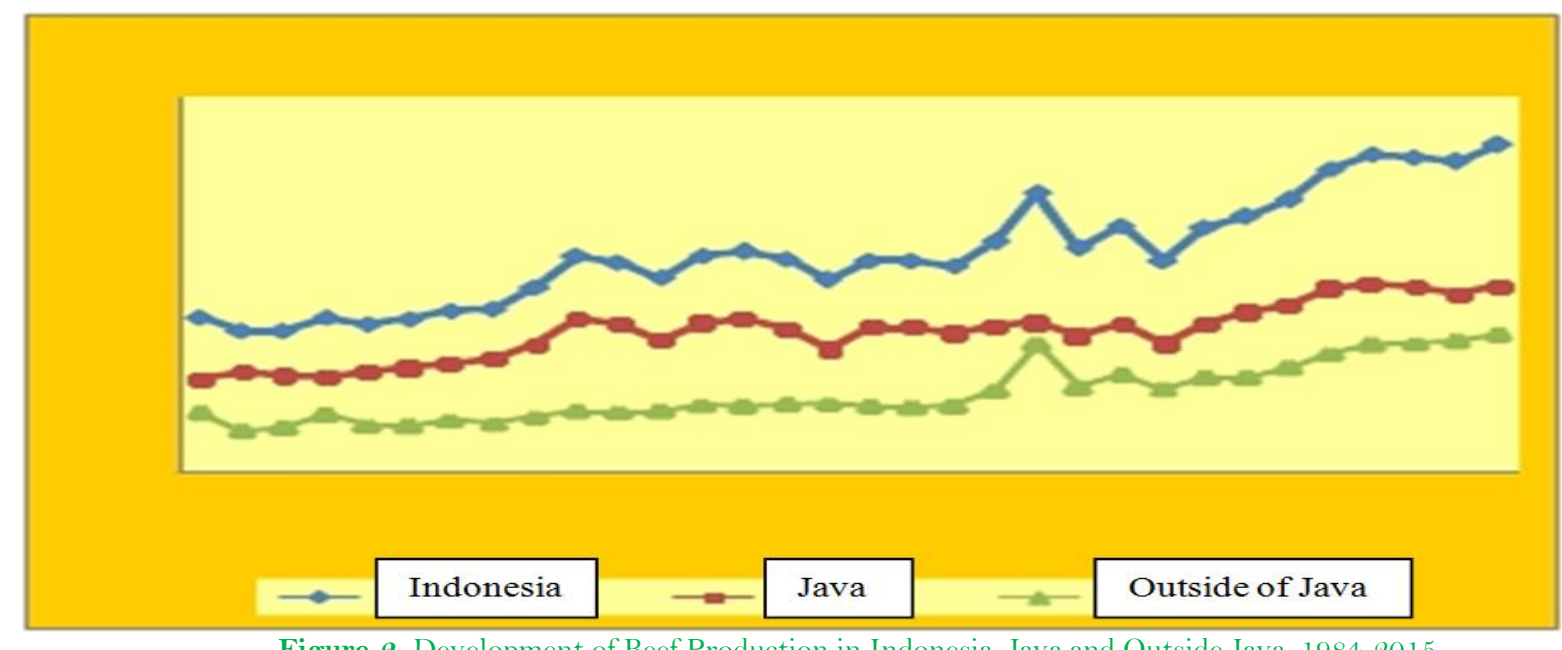

(Source: Nuryati et al. (2015))

Although there is more beef cattle outside Java than in Java, beef production in Java is higher than outside Java. In 1984 beef production in Java amounted to 151.58 thousand tons or $61.00 \%$ of total beef production in Indonesia, then in 2015 it increased to 301.35 thousand tons or $59.51 \%$ of total beef production in Indonesia, however, the high rate of cuts in Java is inseparable from the role of supply of cattle from outside Java.

As comparison, Kubkomawa et al. (2018) inform that Beef cattle production and marketing dynamics in Nigeria involves pastoralism, home fattening, buying, selling, brokering, retailing, dealing, transporting and butchering. It is, therefore, concluded that, beef cattle production and marketing in the study area is a profitable venture if special consideration is given to tackle the bottlenecks militating against the smooth production, transactions and efficient marketing processes. However, Amejo et al. (2018) stated that Intensified feeding strategies from existing sources, improvement through rearing and herd management viewed to make potential improvement in livestock production and could reintegrate the strategies of the livelihood in smallholder mixed system. Where variability assessment in herd demographic parameters could an opportunity suit livestock intensification interest to support the sustainable development of the rural poor.

The beef industry in the United States consists of several distinct production levels ranging from the cow-calf producer at the lowest level to the final consumer. These sectors face varying levels of profitability, degrees of market power, conflicting goals, and price signals. Environmental regulations involve questions of what costs are involved, who is in a position to pay these costs, and whether market prices are capable of signaling different environmental practices. Understanding the relationships within the beef industry may allow researchers to finetune analyses of environmental issues in the beef industry (Outlaw et al., 1997).

According to Subak (1999) the environmental impacts of a specific intensive US feedlot system and a traditional African pastoral system are calculated using a methodology that includes the major land-use and energy-related emissions. Although assessments of carbon dioxide emissions find much greater impacts related to the US feedlot mode, the methane intensity of the pastoral mode is much larger because of the lower productivity of these systems. It is found that when indirect sources, which include emissions from fossil fuels and foregone 
carbon storage on appropriated land, are considered as well as emissions from enteric fermentation and wastes, the social costs of the feedlot system at $15 \mathrm{~kg} \mathrm{CO} 2$ equivalent $/ \mathrm{kg}$ beef are more than double that of the pastoralist system. Accordingly, the results of the more complete greenhouse gas emissions analysis were found to converge somewhat with the biophysical capital alteration approach in this example, although it is also argued that the entropy-based environmental indicators may have limited use in evaluating agro-ecosystems' contribution to climate change. Given an assumed, albeit uncertain, climate change impact value, a tax on beef production of about $9 \%$ of the unit price would represent the upper limit of the shadow costs of the associated greenhouse gas emissions flux from feedlot systems as estimated here, and a central value would correspond to a tax of about $4 \%$.

\subsection{Beef Consumption}

The amount of beef consumption is determined by the population and consumption of beef per capita. The increasing awareness of the Indonesian people about the importance of animal protein, further increasing national beef consumption. Based on the 2014 National Socio-Economic Survey (SUSENAS) data cited by Nuryati et al. (2015) in the period 1993-2014 Indonesian beef consumption per capita per year tended to increase, with an average of $2.08 \mathrm{~kg} /$ capita / year. Consumption that creates demand for meat in Indonesia in the coming years tends to increase. In 2013 the consumption of beef was 567.31 thousand tons, and in 2019 consumption increased to 642.76 thousand tons.

However, predictions of beef consumption made by Nuryati et al. (2015) for 2015 underestimate, while the prediction of beef consumption made by the Ministry of Trade seems overestimate. Ningsih (2015) quoted a statement from the Secretary of the Directorate General of Domestic Trade of the Ministry of Trade (Kemendag) Suhanto that in 2015 Indonesia had a beef deficit of 237.89 thousand tons or equivalent to 1.39 million live cattle. The calculation is based on the level of beef consumption in 2015 of $2.6 \mathrm{~kg}$ per capita per year with a population of $255,461,700$ people, so that the demand for beef in 2015 reached 653,982 tons or equal to 3,843,787 live cattle, but the local capacity was only 2,445. 577 cows live, so there is a deficit in the availability of cattle as much as 1.39 million cows or equivalent to 237.89 thousand tons of meat. To cover the deficit, based on the calculation of beef coordination at the Office of the Coordinating Ministry for Economic Affairs on August 31, 2015, the supply of imported beef in the form of 773,149 live cattle and 83.26 thousand tons of frozen meat was determined.

\section{Projections of Beef Production and Consumption}

Based on national beef production data (without imports) and national beef consumption, projections can be made in the next few years, then compare whether the balance of production and consumption of Indonesian beef is surplus or deficit. Nuryati et al. (2015) from the Agriculture Data and Information Center, Ministry of Agriculture of the Republic of Indonesia, made the projections of national meat production and consumption in the next five years (2013-2019) using multiple regression models, the results of which are presented in Table 1.

In Table 1 it appears that national beef production for 2013-2019 is projected to increase with an average growth rate of $4.81 \%$ per year as the local cattle population increases. Likewise for beef consumption from 20132019 is predicted to increase with an average growth from 2015-2019 of 2.11\%. Predictions of higher production growth than growth in consumption of beef have not been able to offset consumption, so that beef deficits still occur until 2019.

Table-1. Projections for National Meat Production and Consumption, 2013-2019

\begin{tabular}{|c|c|c|c|c|}
\hline \multirow[t]{2}{*}{ Year } & \multicolumn{2}{|l|}{ Production (000 tons) } & \multirow{2}{*}{$\begin{array}{l}\text { Consumption } \\
\text { National Beef } \\
\text { tons })\end{array}$} & \multirow{2}{*}{$\begin{array}{lr}\text { Surplus } & / \\
\text { Deficit } & (000 \\
\text { tons }) & \\
\end{array}$} \\
\hline & $\begin{array}{l}\text { Production of Carcass } \\
\text { Meat(000 Tons) }\end{array}$ & $\begin{array}{ll}\text { Pure } & \text { Meat } \\
\text { Production(000 Tons) }\end{array}$ & & \\
\hline 1 & 2 & 3 & 4 & 5 \\
\hline 2013 & 504.8 & 403.85 & 567.31 & -163.45 \\
\hline 2014 & 497.67 & 398.14 & 595.11 & -196.97 \\
\hline $\left.2015^{*}\right)$ & 523.93 & 419.14 & 613.11 & -193.97 \\
\hline $\left.2016^{* *}\right)$ & 583.14 & 466.51 & 623.48 & -156.97 \\
\hline $\left.2017^{* *}\right)$ & 606.73 & 485.38 & 636.39 & -151.01 \\
\hline $\left.2018^{* *}\right)$ & 636.96 & 509.57 & 641.33 & -131.76 \\
\hline $\left.2019^{* *}\right)$ & 666.69 & 533.35 & 642.76 & -109.41 \\
\hline Rata-RataPertumbuhan & 4.81 & 4.81 & 2.11 & -5.60 \\
\hline
\end{tabular}

\section{Source: Nuryati et al. (2015)}

Information:

Column $5=$ column 3 - column 4 .

*) Production of Provisional Figures, DG PKH

**) Consumption of Pusdatin estimates.

The highest beef deficit occurred in 2014 which was equal to 196.97 thousand tons and the lowest was predicted in 2019 at 109.41 thousand tons, this was indicated by Indonesia still importing beef cattle from abroad, namely from Australia and New Zealand until 2015. Seeing the deficit beef until 2019 tends to decline, it is expected that beef imports will decline. However, as a note, the reduction in the beef deficit is only calculated based on household consumption, while the demand for beef outside the household which is estimated to be quite large has not been calculated. Indonesia is still importing beef from abroad, namely from Australia and New Zealand until 2015.

\section{Volatility of Beef Price \\ 5.1. Development of Beef Price}

Observing the development of beef prices over the past five years (2011 - February 2016), it appears that beef prices tend to increase, on average $15 \%$ per year and never once a price decline from the previous year (Figure 3) 


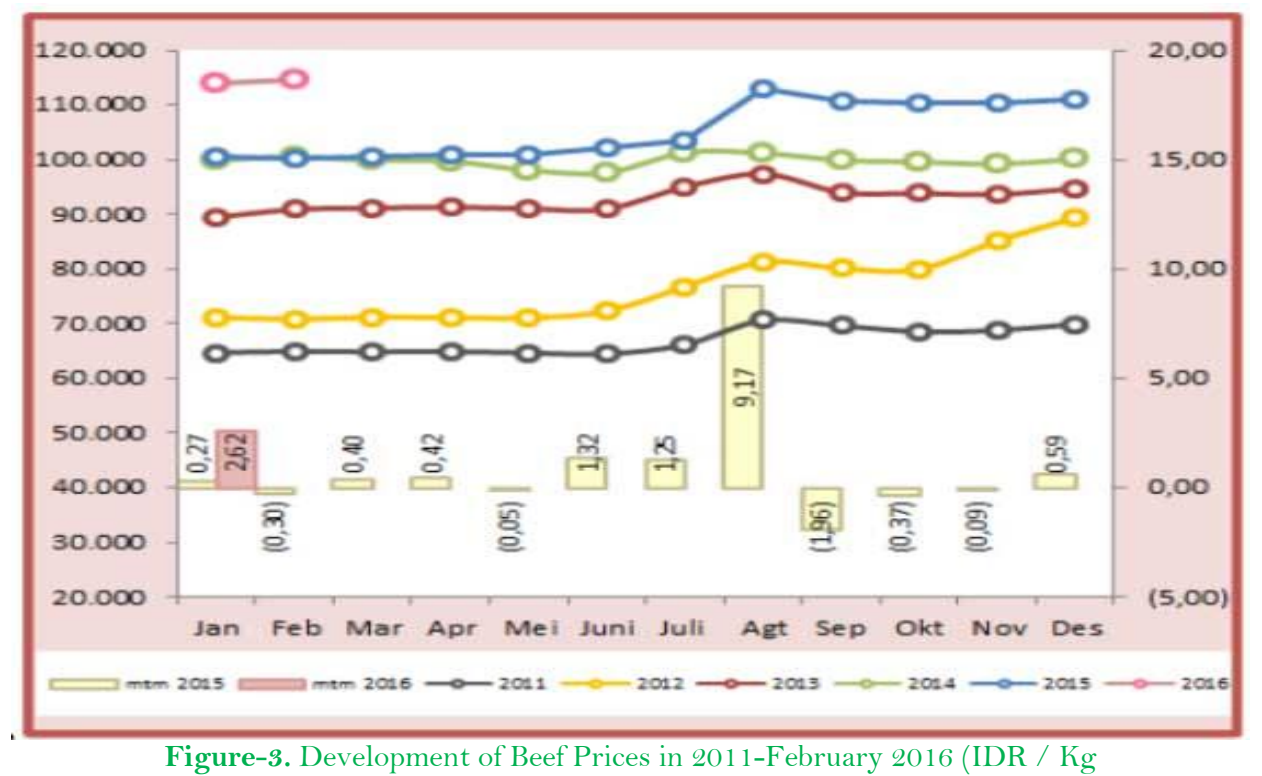

(Source: CBS Jakarta in Anonymous (2016))

In Figure 3, there is a pattern of increases and decreases in beef prices in the same month in the last five years. At the beginning and end of the year there was an increase in prices, before the fasting month there was an increase and the highest increase in prices when approaching Eid. During the last five years (2011-2016), Eid fell in August and July. Likewise, the pattern of decline was in February and May, then in September, October and November it decreased. In September the decline was quite large compared to other months, because Eid had ended towards a normal equilibrium price, but the decline for the three months was only one third of the increase before Eid.

Since beef accounts for $71 \%$ of meat consumption in Nigeria, efficient functioning of the beef market network is very important in Nigeria's development. Empirical results showed that retail price growth rates were highest in 2002. Growth was highest in Benue Market in 2002 (99.7\%), Sokoto Market in 2009 (95.4\%) and Imo Market in $2002(54.9 \%)$. Growth rates were generally stable in 2001 except in Kwara Market. The lowest growth rates were recorded in Benue Market (-35.1\%) and Imo Market (-14.5\%) in 2003. Average growth rates were highest in Borno Market (17.4\%), Sokoto Market (16.0\%) and Bauchi Market (15.6\%) while it was least in Lagos Market (11.3\%)(Bobola et al., 2015).

\subsection{Beef Price Calculation of Kadin and Government Version}

According to the calculation of the Indonesian Chamber of Commerce and Industry/Kadin (Martaon, 2015; Chandra, 2016) the price of local beef sold in the market for IDR $120,000 / \mathrm{kg}$ is considered reasonable with details: the price of live beef per kilogram is around IDR 43,000/ $\mathrm{kg}(=\mathrm{US} \$ 3)$, then the price has doubled when it has been cut into a carcass of IDR $86,000 / \mathrm{kg}$. Plus the cost of cutting around IDR 20,000/ kg in slaughterhouses (Rumah Potong Hewan, RPH). Coupled with transportation costs to the market around IDR 10,000 to IDR 15,000. If accumulated the price of retail meat in the public market becomes IDR 115,000 to IDR 120,000 per $\mathrm{kg}$ (IDR 83.00 $\rightarrow$ IDR $86,000+$ IDR $20,000+$ IDR 9,000 - IDR 14,000). However, the price of live beef according to the Kadinversion is IDR 43,000 per kg, the weight of live cattle is above the calculation of government prices (Ministry of Agriculture) of 38,000 rupiah per kilogram.

\subsection{Deficit and Cartel Behind the Volatility of Beef Prices}

The beef deficit in Indonesia triggered a rise in prices, and this price increase tempted the beef business actors to form a cartel. Kusuma (2013) who cites Oxford dictionaries, cartels or cartels defined, "Cartel is a group of separate business firms." That is, the cartel is a group (group) of various different business legal entities that work together to increase their respective profits without going through business competition with other business actors. They are a group of producers or business owners who make an agreement to make pricing, distribution arrangements and distribution areas, including limiting supply.

Anonymous (2017) stated that the Ministry of Finance signed a cooperation agreement with the Business Competition Supervisory Commission (KPPU) to reduce the price of beef in the market with a very thick cartel practice. The Indonesian beef market is not only filled with local production, but also filled with imported meat. Although beef imports and meat products have increased to a dozen times, the prices have continued to stay high. This reinforces the suspicion of cartel practices in the meat market. For this reason, the government and KPPU are preparing fines of up to IDR 25 billion to provide a deterrent effect.

According to Idris (2016) who quoted the statement of the Business Competition Supervisory Commission (KPPU), KPPU officially sentenced 32 feedlot companies to accusations of carrying out cartel practices or business conspiracy. Thirty-two feedlots were considered to have carried out a cartel through an agreement within the Indonesian Meat Producer and Feedlot Association (Apfindo). The 32 feedlot companies were brought by the KPPU to the trial because they were considered to be practicing unfair business competition by holding a supply of cattle. This makes the price of beef in Jakarta-Bogor-Depok-Tangerang-Bekasi (Jabodetabek) had penetrated above IDR $170,000 / \mathrm{kg}$. Deputy Chairman of the Corruption Eradication Commission (Komisi Pemberantasan Korupsi, KPK) Laode Muhammad Syarif (Puspitasari, 2017) ensured that bribe judges of the Constitutional Court Patrialis Akbar, BasukiHariman, carried out a beef cartel. Indications were revealed because of the many ministries and agency stamps found in Basuki's office at PT SumberLaut Perkasa related to meat import business. According to Laode, the high price of beef at that time was the work of a meat cartel that monopolized the market. Director General of Taxes-Ken Dwijugiasteadi (Rahmah, 2017) stated that the government would impose a high tax on business entities or businessmen suspected of being a cartel in the beef import trade business, whose calculations 
were $25 \%$ plus sanctions up to $48 \%$. According to Ken, his office found allegations of fraud committed by employers to outsmart taxes. Ken further said that his party is now exploring and investigating 82 beef-related business entities. It is said that business owners are all that, but they open branches and distribution everywhere, and they do cartels with their own companies or branches, and they set prices as they please, so the price of beef becomes high.

\section{Conclusions and Recommendations}

\subsection{Conclusions}

1. The population of beef cattle in Indonesia tends to increase by an average of $2.72 \%$ per year in the period 2000-2016, namely in 2000 as many as 11,008,017 birds, in 2010 as many as 13,581,570 tails, and in 2016 as many as $16,092,561$ tails.

2. The rate of increase in beef consumption is higher than the rate of increase in national beef production, resulting in beef deficits. Based on the project of beef production and consumption, until 2019 Indonesia is still deficit of beef or not yet self-sufficient in beef.

3. The volatility of beef prices reaches IDR 150,000 per kg, not only because of the national beef deficit, so prices move up, but also the cartel of fellow beef business people. Even the government through the Business Competition Commission (Komisi Pengawas Persaingan Usaha, KPPU) has imposed fines on 32 feedloters.

\subsection{Recommendations}

1. Reducing the turmoil of volatility of beef prices on the public market, for the time being or in the short term the government can open bigger beef import tapes to meet domestic demand, but for permanent and long-term, the government must nurture farmers and prospective local cattle breeders intensively and extensively with various incentive programs, so that farmers and prospective farmers are more interested in raising cattle.

2. The cattle insurance program that was recently launched by the government in August 2016, needs to be disseminated and local cattle farmers need to be educated on the benefits of participating in this cattle insurance.

\section{References}

Amejo, A.G., Y.M. Gebere, U. Dickoefer, H. Kassa, T. Tana and P. Lawrence, 2018. Herd dynamics and productivity performance modeling of livestock in smallholder crop-livestock systems in Southwestern Ethiopia. International Journal of Veterinary Medicine and Animal Husbandry, 3(1): 17-24.

Anonymous, 2012. Economic analysis and marketing of Bali Cows. In the book Bali Cow Original Indonesian Genetic Resources. Denpasar Bali. Publisher of Bali Cow Study Center and Udayana University. pp: 241-267.

Anonymous, 2016. National beef price development pattern. In SAPIBAGUS Web. Available from http://www.sapibagus.com/2016/03/26/pola-perkembangan-harga-daging-sapi-nasional-2011-2016.

Anonymous, 2017. The government seriously combats beef cartel. TRIBUNNEWS.COM, JAKARTA. Available from http://www.tribunnews.com/ bisnis/2017/03/03/pemerintah-serius-perangi-kartel-daging-sapi.

Bobola, O., T. Mafimisebi and E. Ikuemonisan, 2015. Price Fluctuations, Linkages and Causality in the Nigerian Beef Market. Journal of Fisheries and Livestock Production, 3(135): 2. Available at: https://doi.org/10.4172/2332-2608.1000135.

CBS, 2017. Animal husbandry statistics: Beef cattle population in 2000-2016. On the web. Jakarta: CBS.

Chandra, A.A., 2016. This is the Calculation of Kadin About the Price of Beef IDR 120,000/Kg. In Detik of Finance. Available from https://finance.detik.com/berita-ekonomi-bisnis/d-3232978/ini-perhitungan-kadin-soal-harga-daging-sapi-rp-12000okg [Accessed June 14, 2016].

Dwiyanto, K. and I. Mahendri, 2013. The role of Bali Cows in realizing sustainable national meat self-sufficiency. In Proceedings of the Bali Cow National Seminar The Role of Bali Cows in Realizing Sustainable National Meat Self-sufficiency, Bali. pp: 1-26.

Idris, M., 2016. KPPU Fines 32 Beef Cartel Companies, The Highest is IDR 21 Billion. In Detik Finance. Available from https://finance.detik.com/berita-ekonomi-bisnis/d-3194665/kppu-denda-32-perusahaan-kartel-daging-sapi-tertinggi-rp-2 1miliar.

Kompas, M., 2017. Songs of self-sufficiency in beef with insurance. Jakarta: Publisher of PT Kompas Media Nusantara.

Kubkomawa, H.I., S. Adamu, C. Achonwa, K. Adewuyi and I. Okoli, 2018. Beef production and marketing in Nigeria: Entrepreneurship in animal agriculture. International Journal of Veterinary Sciences and Ani mal Husbandry 2018, 3(2): 26-40.

Kusuma, L., 2013. Understanding the definition of cartel, monopoly and business competition. In Journal of Nusa Bangsa. Available from http://leo4kusuma.blogspot.com/2013/03/memahami-pengertian-kartel-monopoli-dan.html\#.XEccl95B8ap.

Martaon, A., 2015. Calculation of feedloter version of beef prices. In Metro Tv News.Com. Available from http://jabar.metrotvnews.com/read/2015/09/16/431504/perh.

Muladno, 2012. Application of breeding technology for increased goal production and national beef quality. In the Proceedings of the National Seminar on Increasing Production and Quality of National Bali Beef, Bali September 14, 2012. Center for Bali Cattle Studies and Udayana University. pp: 1-15.

Ningsih, D., 2015. Beef deficit reaches 238,000 tons. In SATU.COM NEWS. Available from http://www.beritasatu.com/ekonomi/305538defisit-daging-sapi-2015-capai-238000-ton.html.

Nuryati, L., B.N. Waryanto and R. Widaningsih, 2015. Outlook on agricultural commodities in livestock sub sector. Beef. Published by Dara Center and Agricultural Information System, Secretariat General of the Ministry of Agriculture, Jakarta. pp: 65.

Outlaw, J.L., D.P. Anderson and D.I. Padberg, 1997. Relationships between market price signals and production management: The case of fed beef. Journal of Agricultural and Applied Economics, 29(1): 37-44.

Puspitasari, M.A., 2017. Patrialis bribery case, here's the twists and turns of beef cartel. In Tempo. Available from https://m.tempo.co/read/news/2017/02/01/.

Rahmah, G., 2017. Will beef cartel subject to high taxes. In TEMPO.CO.BISNIS. Available from https://bisnis.tempo.co/read/851950/kartel-daging-sapi-bakal-dikenakan-pajak-tinggi.

Subak, S., 1999. Global environmental costs of beef production. Ecological Economics, 30(1): 79-91. Available at: https://doi.org/10.1016/s0921-8009(98)00100-1

Supardi, S.W., 2009. Bali Cow "Pearl" from Bali. Denpasar, Bali: Udayana University Press. pp: 65. 